\title{
Erasmus Öğrenci Hareketliliği ile Anadolu Üniversitesi'ne Gelen Öğrencilerin Kütüphane Memnuniyet Düzeyleri
}

\author{
The Library Satisfaction Levels of Students Who Came to \\ Anadolu University via Erasmus Student Mobility Program
}

\author{
Mesut KURULGAN * ve Halime ATIL YÖRÜ **
}

\begin{abstract}
Öz
Üniversite kütüphanelerinde sunulan hizmetlerin kullanı gereksinim ve beklentilerini karşılaması, onlarda tatmin duygusu yaratması, günümüzde kullanıcı odaklı hizmet anlayışını benimseyen kütüphanelerin verimliliğinde önemli bir etmendir. Bu yüzden kütüphanelerin, kullanıcılara sunulan hizmetlere yönelik beklenti ve memnuniyet düzeyleri hakkında bilgi edinmeleri önemli bir konudur. Küreselleșme olgusu ile birlikte kütüphaneler, kullanıcı kitlesi ve hizmet politikalarında önemli dönüşümler yaşanmaktadır. Avrupa öğrencilerinin hareketliliğine yönelik küresel bir eylem planı olan Erasmus, Avrupa Birliği ülkeleri ile aday ülkelerin yükseköğretim kurumları arasındaki işbirliğini destekleyip geliştirmek amacıyla, 1987 yılında başlatılmıştır. Türkiye sözü edilen programa 2004 yılında katılmıştır. Bu araştırmanın amacı, küresel bir üniversite olan Anadolu Üniversitesi'ne yurt dışından Erasmus Programı ile gelen öğrencilerin kütüphane memnuniyet düzeylerini belirlemek ve burada elde edilen bulgularla geldikleri üniversitelerin kütüphaneleri ile ilgili algıladıkları memnuniyet düzeylerini karşılaştırmaktır. Çalışmanın verileri, 2010-2011 öğretim yılında, Erasmus öğrencisi olarak Anadolu Üniversitesi'ne gelen 74 öğrenciden anket yöntemi ile sağlanmıştır. Verilerin toplanmasında, "Anadolu Üniversitesi Kütüphane ve Dokümantasyon Merkezi Erasmus Öğrenci Memnuniyet Anketi" kullanılmıştır. Toplam 13 soru ile öğrencilerin kütüphane memnuniyet düzeyi saptanmaya çalışılmıştır. Verilerin çözümlenmesinde IBM SPSS Statistics 19 programından yararlanılmıştır. Çalışmanın sonucunda Erasmus Değişim Programı ile Anadolu Üniversitesi'ne gelen öğrencilerin büyük bir kısmının kütüphane hizmetlerinden memnun oldukları belirlenmiştir.
\end{abstract}

Anahtar sözcükler: Kullanıcı memnuniyeti, Erasmus Öğrenci Hareketliliği Programı, Üniversite öğrencileri, Üniversite kütüphaneleri, Anadolu Üniversitesi, Anadolu Üniversitesi Kütüphanesi

\begin{abstract}
Library services' meeting the expectations and needs of the users and causing satisfaction are important factors in the efficiency of libraries that accept the user-focused service understanding. Therefore, libraries' getting information about the expectations and satisfaction levels of services is a significant topic. By the fact

* Doç. Dr., Anadolu Üniversitesi Açıköğretim Fakültesi, Eskişehir. (mkurulgan@anadolu.edu.tr)

** Uzm., Anadolu Üniversitesi Kütüphane ve Dokümantasyon Dairesi Başkanlığı, Eskişehir. (hatil@anadolu.edu.tr)
\end{abstract}


of globalization, there are significant changes in the community of library users and servicing policy. Erasmus, an action to plan aiming at mobility of European students is started in 1987 by the purpose of improving and supporting relations between European countries and nominated countries. Turkey participated to this program in 2004. The purpose of this study is to find out library satisfaction levels of Erasmus students at Anadolu University which is a global university and to compare obtained data here and their satisfaction levels about libraries of their universities. The data of the study were collected via a questionnaire given to 74 Erasmus students at Anadolu University in 2010-2011 academic years. In the collection the data, "Anadolu University Library and Documentation CenterErasmus Student Satisfaction Questionnaire" was used. A total of 13 questions were asked to find out satisfaction levels. In the analysis of the data IBM SPSS Statistics 19 program was used. At theend of the study, most of the students who came to Anadolu University via Erasmus program were found to be satisfied with library services.

Keywords: User satisfaction, Erasmus Student Mobility Program, University students, Academic libraries, Anadolu University, Anadolu University Library

\section{Giriş}

Avrupa Birliği $(A B)$, Avrupa'nın yüzyıllar boyunca edindiği deneyimle ve oluşturduğu ortak ilkeler temelinde, İkinci Dünya Savaşı sonrasında oluşturulmuş bir yapıdır. Kuruluş yıllarında 6 üyeli çekirdek bir yapıyla oluşan Birlik, farklı tarihlerde yeni üyelerin katılımıyla günümüzde sayısını 27'ye çıkarmıştır. Yaklaşık 500 milyon nüfusuyla küresel bir güç haline gelen $A B$, ortak kültürün bir sonucu olarak ortaya çıkan demokrasi, barış, özgürlük, fırsat eşitliği, sosyal adalet, insan hakları ve hukukun üstünlüğü gibi değerleri savunmaktadır. Gücünü bilgi ve bilimden alan $A B$, sözü edilen değerlere sahip çıkmak ve Ortak Avrupa fikrini güçlendirmek için önemli bir araç olan "eğitim"den yararlanmaktadır (Bir bakışta AB, 2011; Bologna Projesi, 2012, Göksan, Uzundurukan ve Keskin, 2011, s. 191-192).

"Eğitimde Avrupalılık" boyutunu vurgulayan Avrupa eğitim programlarının yükseköğretim ile ilgili bölümü olan ve 2012 yılında 25. yaşını tamamlayan Erasmus Programı, AB'nin diğer eğitim programları arasında oldukça önemli bir yere sahiptir. Türkiye'nin 2004 yılı itibariyle dahil olduğu Erasmus Programı kapsamında, her yıl artan bir biçimde, programa katılan çeşitli eğitim kurumları arasında öğrenci ve öğretim elemanı değişimi sağlanmaktadır. Bu değişim sayesinde, Erasmus Programı́nın uluslararası ortaklık ve işbirliğini sağlama, eğitimde fırsat eşitliğini yaygınlaştırma, eğitimin niteliğini yükseltme, çok kültürlülüğü inşa etme, Avrupa'nın değişik ülkelerindeki en iyi uygulamaları Avrupa'daki tüm ülkelerin yararına sunma ve nitelikli insangücünü oluşturma gibi akademik, sosyal ve kültürel amaçları gerçekleştirdiği açıkça görülmektedir (Certel, 2010, s. 1).

Certel (2010), Erasmus Programı́na katılan Türk öğrencilerin akademik yaşantılarıyla ilgili literatürde önemli bir araştırma gerçekleştirmiştir. Araştırmada elde edilen bulgulara göre; her bir Avrupa yükseköğretim alanı katılımcısı ülkenin kendi geçmişine ve farklı gereksinimlerine göre farklı amaçlar taşıdıkları; bu nedenle bazı uygulamalarda 
daha fazla istekli iken, bazılarında ise isteksiz oldukları belirlenmiş; bunun yanında, katılımcıların maddi kaynaklar ve eğitim politikaları gibi belirgin ortak çıkarlarda birleşebildikleri saptanmıştır.

Bununla birlikte, Erasmus öğrencilerinin kütüphane kullanımları üzerine yapılmış bir çalışma bulunmamaktadır. Bu nedenle hazırladığımız bu çalışmada, Erasmus Programı kapsamında yurt dışından Anadolu Üniversitesi'ne gelen öğrencilerin kütüphanede verilen hizmetler hakkındaki görüşlerinin saptanması ve bunların geldikleri üniversite kütüphanelerinde algıladıkları memnuniyet düzeyleri ile karşılaştırılması, sözü edilen araştırma eksikliğinin bir ölçüye kadar da olsa giderilmesi ve alanda yapılacak çalışmalara da yardımcı olunması amaçlanmaktadır.

Erasmus gibi çeşitli küresel öğrenci ve bilim insanı değişimi etkinlikleri, dünyada ve Türkiye'de üniversite kütüphanelerinin kullanıcı türünde çeşitlilik yaratmaktadır. Türü ne olursa olsun bütün kullanıcılarına etkin ve verimli bir biçimde bilgi ve belge hizmeti sunmak için stratejiler geliştiren günümüz üniversite kütüphaneleri, hizmetlerini değerlendirmek için kullanıcı memnuniyet anketlerine başvurmaktadır.

Bilgi ve belge yönetimi alanında yapılan literatür taraması sonucu, yerli ve yabancı kaynaklarda, kütüphanelerde kullanıcı memnuniyeti üzerine yapılan çeşitli araştırmalara (Çapar, 1990; Alkan, 1992; Erdem, 1995; Danuta, 1996; Aslan, 1999; Uçak, 1997; Çukadar, 1999; Karakaş, 1999a; Karakaş, 1999b; Karakaş, 1999c; Nitecki ve Hernon, 2000; Hiller, 2001; Üstün, 2001; Bulgan, 2002; Hitchingham ve Kenney, 2002; Yılmaz, 2003; Adomi ve Iwhiwhu, 2004; Yılmaz, 2004a; Yılmaz, 2004b; Akbayrak, 2005; Çanak Akbaytürk, 2006; Kapucu, 2007; Keser, 2007; Kılıç, 2007; Kurulgan, 2007; Bozkurt, 2008; Tabak, 2009; Öndoğan, 2010; Milli Kütüphane, 2011; Çağlayan, 2011; Karahan, 2012; Citti, Politi, Sabattini ve Semenzato, 2012; Hossain ve Islam, 2012; Powelson ve Reaumet, 2012; Shafique, Rehman ve Mahmood, 2012) ulaşılmasına rağmen, farklı bir kullanıcı grubunu oluşturan Erasmus öğrencilerinin -özel bir boyutta- memnuniyet düzeylerinin incelenmediği anlaşılmaktadır.

\section{Kuramsal Çerçeve}

\section{Erasmus Programının Misyonu}

Uluslararası öğrenci hareketliliği (Erasmus), yükseköğretimde kişinin toplumsallaşarak öğrenmesinin ve öğrendiklerini benimsemesinin önemli bir ölçütü olarak kabul edilmektedir (Kehm, 2005, s. 18). Erasmus programının misyonu, Avrupa'da yükseköğretimin kalitesini artırmak ve Avrupa'daki durumunu güçlendirmektir (Bural, 2007, s. 74).

Adını Hollandalı filozof Desiderius Erasmus'tan alan Program, Avrupa'daki yükseköğretim kurumları arasındaki iş birliğinin geliştirilmesi yoluyla, üniversiteden mezun olan bireylerin işgücü piyasasında istihdam oranını artırarak, iş dünyası ile 
üniversiteler arasındaki ilişkilerin güçlendirilmesine odaklanmaktadır (Sarıtaş, 2011, s. 23). Bu program, yükseköğretim kurumlarının ortak projeler üretip hayata geçirmeleri ile kısa süreli öğrenci ve akademik personel değişimi yapabilmeleri için hibe niteliğinde karşılıksız mali destek sağlamaktadır (Certel, 2010, s. 20). Buradan hareketle, Erasmus Programı́nın temel amaçları aşağıdaki biçimde sıralanabilir (Bural, 2007, s. 76):

$\diamond$ Eğitimin, özellikle üye ülke dillerinin öğretimi yoluyla gerçekleştirilmesi,

$\diamond \quad$ Avrupa ülkeleri arasında öğrenci ve akademik personel hareketliliğinin sağlanması ve diplomaların karşılıklı tanınması,

$\diamond$ Üniversiteler arasında iş birliğinin geliştirilmesi,

$\diamond \quad$ Üye ülkelerin eğitim sistemlerinin ortak sorunları hakkında bilgi ve deneyimlerin aktarılması,

$\diamond$ Açık ve uzaktan öğretim sisteminin geliştirilmesi,

$\diamond$ Teknolojik gelişmelere uyum sağlanması, mesleki eğitimin iyileştirilmesi ve mesleki eğitime ulaşma olanaklarının artırılması.

\section{Erasmus Programı Uygulamaları ve Sonuçları}

Başlangıcı 1987 yılına dayanan Erasmus Programı, 1995 yılında Socrates Programı çatısı altında birçok bağımsız programla birleştirilmiştir. Socrates Programı 1999 yılında sona ermiş ve 2000 yılında Socrates II programı yürürlüğe girmiştir. Bu program, 2007 yılından itibaren de "Hayat Boyu Öğrenme Programı" adı altında yaşamını sürdürmektedir. Program, sunduğu hareketlilik olanağı ile Avrupa halklarının birbirlerini algılamasındaki önyargıların üniversite çevrelerinde kırılmasına hizmet etmektedir. Erasmus Programı ile 1987 'den günümüze kadar 1,5 milyondan fazla yükseköğretim öğrencisi, öğrenim hayatının bir bölümünü başka bir Avrupa ülkesinde geçirmiş; bu süreçte bulunduğu ülkenin insanlarını ve kültürünü tanıma fırsatını da elde etmiştir. Program'da, 2012 sonu itibarıyla, 3 milyon öğrencinin Erasmus'a katılımı hedeflenmektedir (Erasmus, 2012).

Erasmus Programı ile ilgili yapılan araştırmalarda ulaşılan sonuçlar şunlardır (Bural, 2007, s. 78-79; Mirici ve Saka, 2009, s. 149; Certel, 2010, s. 353):

$\diamond$ Program, ailelere çocuklarını yurtdışında okutabilme imkânı vermiştir. Erasmus'tan yararlanan öğrencilerin \%80'den fazlası ailelerinde bu olanağı bulabilen ilk kişilerdir.

$\diamond$ Programa katılan öğrencilerin yaklaşık \%90'ı yurtdışında öğrenim görme dönemlerini yararlı ya da çok yararlı olarak değerlendirmişlerdir.

$\diamond$ Erasmus Programı́nı tamamlayan bireyler, kendilerini çok daha yetenekli hissettiklerini ve gidilen ülke hakkında bakış açılarını değiştirdiklerini dile getirmişlerdir.

$\diamond \quad$ Öğrenciler yabancı dil yeteneklerini geliştirme olanağı bulmuş ve ikinci bir dil kullanarak çalışabilme oranı, Erasmus'a katılmayan öğrencilere kıyasla, \%40 ile \%60 arasında artmıştır. 
$\diamond$ Öğrencilerin ev sahibi ülkelerde yaşadığı sorunlar; öğretim dili, öğretim ve öğrenim biçimindeki farklılıklar, öğretim elemanları ve diğer öğrencilerle yaşanan problemler, finansman yetersizliği ve sosyo-kültürel uyum sorunları olarak kendini göstermektedir.

$\diamond$ Program, öğrencilerin kişisel gelişimlerini artırarak, mezuniyet sonrası iş arama sürelerini kısaltmıştır.

\section{Kullanıcı Memnuniyeti ve Önemi}

Kütüphaneler, sosyal ve kültürel kuruluşlar arasında varlık gösteren ve kâr amacı gütmeyen örgütlerdir. Örgütlerin, kâr amacı gütsün ya da gütmesin; müşteri memnuniyetinin arttırılması, işgörenlerin yaratıcı yeteneklerinin geliştirilmesi, güven duygularının oluşturulması, örgütün çevredeki öneminin ve devamlılığının sağlanması, örgütün kendi içinde tutarlılığının sürdürülebilmesi ve örgütsel hizmetlerin verimli olması için iyi yönetilmeleri gerekmektedir. Kütüphaneler amaçlarına verimli bir biçimde ulaşabilmek için faaliyetlerinde çağdaş yönetim teknik ve ilkelerini benimseyerek uygulamak mecburiyetindedir (Kurulgan, 2009, s. 206). Bu tekniklerin en önemlilerinden biri olan Toplam Kalite Yönetimi (TKY); kalite, kaliteli hizmet, sürekli iyileştirme, kullanıcı memnuniyeti, işgören memnuniyeti, toplumsal sorumluluk, toplam katılımcılık ve sürekli eğitim gibi kavramları içeren çağdaş bir yönetim anlayışıdır (Çukadar, 1999, s. 332).

Kullanıcı, bu yeni yönetim anlayışında "varlık nedeni" olarak ele alınıp, değerlendirilmesi gereken kütüphanenin önemli bir ögesidir. Kütüphanelerin amacı, kullanıcının bilgi ve bilgi kaynaklarına kolayca erişimini sağlamak olunca, kütüphanecilik biliminde yeni kavramlar ortaya çıkmaya başlamıştır. Bu kavramlardan birisi de kullanıcı memnuniyetidir (Erdem, 1995, s. 15).

Memnuniyet, kütüphane kullanıcısının bir hizmet ya da ürünü kullandıktan sonra kendisinde oluşan beğeni veya olumlu düşüncelerle oluşur. Bir başka deyişle, kullanıcının beklediği hizmet kalitesi ile sağlanan hizmet kalitesi arasında karşılaştırma sonucu oluşan bir durumdur. Kullanıcıların hizmet konusundaki beklentilerinin sağlanan hizmet ile eşit durumda olması kullanıc memnuniyetini ortaya çıkarmakta; sağlanan hizmetin beklenilenden daha fazla olması durumunda ise, istenilen kalite oluşmaktadır. İşte bu noktada kullanıcı memnuniyeti en üst düzeyde gerçekleşmiş olmaktadır (Yılmaz, 2004b, s. 205).

Pinder'e (1996, s. 12-13) göre, kullanıcı memnuniyetini etkileyen ögeler şu biçimde sıralanabilir (Yılmaz, 2010, s. 47-48):

$\diamond$ Ürün

Saygınlık (Credibility): Bilgi kaynaklarının güncelliği ve sağladığı faydalar açısından kütüphanenin ünü. 
Anlama/Bilme: Özelde kullanıcının ve genelde de hizmet verilen çevrenin gereksinimlerini bilme.

\section{$\diamond$ Tutundurma/Promosyon}

Elde Edilebilirlik: Sağlanan hizmetler ve kolaylıkların rahatça görülebilir, fark edilebilir ve kullanılabilir olması.

\section{$\diamond$ Yer/Bina}

Erişim/Ulaşım: Yer ve açık bulunma saatlerini kullanıcı beklentilerine göre ayarlama. Güvenlik: Kullanıcıların rahatı, mutluluğu ve kişisel güvenliği.

Somut Fiziksel Durum/ Kolaylıklar: Bina, bilgi kaynakları, donanım ve diğer fiziksel koşulların kullanım kolaylığı.

\section{$\diamond$ Çalışanlar/i̇şgören}

Kibarlık/Nezaket: Kullanıcıya hizmet veren kütüphane çalışanlarının görgü kuralları çerçevesinde davranması.

Samimiyet/içtenlik: Personelin samimi, istekli, kibar ve yardımsever bir davranış sergilemesi.

\section{$\diamond \quad$ Fiziksel Durum}

Görünüm: Kütüphane binasının tasarımı ve personelin genel görünümü.

Atmosfer/Ortam: Kütüphane ortamının çekiciliği ve sakinliği.

Temizlik: Çalışma alanları, depolar ve lavaboların temiz olması.

Rahatlık: Fiziksel ortamın genel havasındaki konfor.

\section{$\diamond$ İşlemler}

Güvenilirlik: Hizmetlerdeki güvenilirlik ve verimlilik.

Illetişim: İşgörenin kullanıcılarla iletişim düzeyi ile sembollerdeki ve rehberlikteki kolay anlaşılırlık.

Erasmus Programı kapsamında gelişmiş ülkelerden Türkiye'ye gelen öğrencilerin, hayal kırıklığına uğramamaları için, üniversite kütüphanelerimizin hizmet kalitesi standartlarını en az gelişmiş ülkeler düzeyine taşımaları ve bu konuda onlarla rekabet içine girebilmeleri gerekmektedir. Bu da ancak, kullanıcı odaklı düşünülerek, onların beklenti ve isteklerini verimli bir biçimde karşılamaktan geçmektedir.

Nitekim çağdaş yönetim yaklaşımına göre merkezi bir konumda olan müşteri/ kullanıcı; planlama, işletim, yönetim ve hizmet kararlarında belirleyici rol oynadığından, bu anlayış kütüphanelerde kullanıcı odaklılık olarak tanımlanmakta ve giderek daha fazla kabul görerek yaygınlaşmaktadır (Yılmaz, 2001, s. 18). 
Whitehall (1994, s. 107-114), kütüphanelerde kullanıcı memnuniyetinin artırılması konusunda şu temel ölçütleri sıralamaktadır (Yılmaz, 2005, ss. 163-164):

$\diamond$ Danışma/referans dermesinin tamlığı/bütünlüğü,

$\diamond$ Veri tabanlarının ve elektronik yayınların tamlığı/bütünlüğü,

$\diamond$ Genel kütüphane dermesinin tamlığı/bütünlüğü,

$\diamond$ Sorulara verilen yanıtların ilgililik düzeyi,

$\diamond$ Yanıtların güncelliği,

$\diamond$ Yanıtlama hızı,

$\diamond$ Hizmetlere erişilebilirlik ve kullanım kolaylığı,

$\diamond$ Bilgi kaynaklarının elde edilebilirliği,

$\diamond$ Ürünlerin sunumunda eşzamanlılık,

$\diamond$ Kullanıcıların ilgi ve gereksinimlerinin dikkate alınması,

$\diamond$ Hizmetler ve dermeyle ilgili bilgi veren kaynaklardaki bilgilerin güncelliği ve tamlığı.

Bütün bunların dışında, Stephens'a (1997, s. 498) göre, kütüphanelerin vitrini olan web sayfalarının biçim ve içeriği, verilen hizmetin kapasitesini yansıtacak ve değerini yükseltecek biçimde olmalıdır (Yılmaz, 2005, s. 165).

Kullanıcı memnuniyeti konusu TKY anlayışının çekirdeğini oluşturur. TKY uygulamaları diğer sektörlerde olduğu gibi, kütüphanelerin de yer aldığı, bilgi sektöründe de önemsenmeye ve uygulanmaya başlamıştır. Kütüphanecilik literatürü uluslararası boyutta incelendiği zaman, gelişmiş ülkelerde müşteri memnuniyeti konusunun oldukça ileri boyutta ele alındığı ve araştırıldığı görülmektedir. Hitchingham ve Kenney (2002) çalışmalarında; kullanıcı memnuniyeti ölçümünün kütüphane yönetimine, hizmet kalitesinin artırılmasına yönelik kararlarda önemli bir veri kaynağı olduğunu belirtmektedirler. Yazarlar, uygulamaya dönük bu çalışmalarında ayrıca memnuniyet ölçümünün kütüphanelerde her yıl sürekli olarak yapılması gereği üzerinde durarak, Virginia Tech Üniversitesi kütüphanelerinde 2001 ve 2002 yıllarında gerçekleştirdikleri ölçümlerin karşılaştırmalı bir analizini yapmaktadırlar.

Adomi ve Iwhiwhu'nun (2004), Nijerya'daki Delta Devlet Üniversitesi Kütüphanesindeki ayrık derme (reserve collection) hizmetlerine karşı kullanıcıların memnuniyet düzeylerini belirlemeye yönelik yaptıkları araştırmada; ayrık dermeye konulacak yayınların belirlenmesinde öğretim elemanlarının görüşlerine yeterince yer verilmediği, birim sorumlusunun sürekli değiştiği ve ayrık materyallerin kullanılacağı odanın yeterince aydınlatılmadığı sonucuna ulaşılmıştır. 
Hossain ve Islam'ın (2012) Dakka Üniversitesi Kütüphanesi'nde hizmet kalitesinin algılanması ve kullanıcı memnuniyeti konusunda yaptıkları araştırmada, kullanıcıların diğer hizmetlere oranla kütüphane çalışma saatlerinden daha memnun oldukları ortaya çıkmıştır.

Powelson ve Raumet'in (2012) yeni hizmet modelinin başarılı olup olmadığı yönünde yaptıkları çalışmada ise, kütüphane personeli tarafından sağlanan bilgi hizmetlerinin \%43 oranında hasta bakım kararları üzerinde doğrudan etkili olduğu saptanmıştır.

Türkiye'de kütüphane kullanıcılarının memnuniyet düzeylerine ilişkin araştırma sayısının gelişmiş ülkelerdeki kadar yoğun olmamasına karşın, konunun bilim insanları ve uygulamacılar tarafından 2000'li yıllardan sonra ele alınarak incelendiği görülmektedir. Çanak-Akbaytürk (2006), Koç Üniversitesi Suna Kıraç Kütüphanesi'nde uyguladığı kullanıc memnuniyet anketleri sonucunda, pazarlama planı çerçevesinde yürütülen çalışmaların öğrencilerin e-kaynak farkındalığını artırdığı; web tabanlı hizmetlerin öğrenci ödevlerinde yetersiz kaldığı; fotokopi hizmetlerinin yetersizliği ve elektronik kütüphane kataloğu kullanımında kullanıcılara daha fazla eğitim programı düzenlenmesi gerektiği vb. verilere ulaşmıştır.

Milli Kütüphane kullanıcılarına dönük yapılan kullanıcı memnuniyet analizinde, kullanıcıların bu kütüphaneyi tercih etme nedenleri arasında en önemlisinin, "dermesinin sayı ve içerik yönünden zengin olması" olduğu anlaşılmaktadır. Ankete katılan kullanıcılar, Milli Kütüphane web sayfasını büyük bir oranla yeterli bulmakta, kütüphanelerarası ödünç verme sistemini verimli bulmakta, kütüphane hizmet ortamları hakkında olumlu görüş bildirmekte ve hijyen koşullarını yeterli bulmaktadır. Ayrıca, kullanıcılar, personel değerlemesi hakkında da olumlu görüş sergilemektedir. Kullanıcıların Milli Kütüphane'den beklentileri arasında; kantinde satılan ürün fiyatlarının düşürülmesi, kantin personelinin olumsuz davranışlarının düzeltilmesi, daha fazla kitabın dijital ortama aktarılması ve fotokopi olanaklarının artırılması gibi konular yer almaktadır (Milli Kütüphane, 2011).

Akbayrak'ın (2005) Ortadoğu Teknik Üniversitesi (ODTÜ) Kütüphanesinde hizmet kalitesi ölçümü üzerine yaptığı araştırmada, kullanıcının kütüphanenin fiziksel koşullarını yeterli bulduğu; kütüphanede bir kafeteryanın bulunması gerektiği; özellikle kitaplarda güncellik sorunun bulunduğu ancak genel anlamda dermenin -nitelik ve nicelik açısından- yeterli olduğu; kütüphane personeli hakkında genelde olumlu düşüncelere sahip olduğu; teknik alt yapı ve donanımın, kütüphane otomasyon sisteminde bazı sıkıntılar yaşanmasına rağmen, genelde yeterli olduğu ve kütüphane çalışma saatlerinin yeterli olmadığı yönünde bulgular elde edilmiştir. Çağlayan'a göre (2011); Ankara'daki üç halk kütüphanesinde kullanıcılar; büyük bir oranla $(\% 73,3)$ kütüphaneyi "ayda 2 kez ve daha fazla" sıklıkla kullanmakta; kütüphane binasını yeterli bulmakta $(\% 81,1)$; dermeyi yeterli görmekte $(\% 76,7)$; aradıkları kaynağa rafta kolay ulaşmakta $(\% 57,8)$; kütüphane personelini nicelik ve nitelik açısından yeterli 
görmekte ve internet olanaklarından yararlandıklarını $(\% 63,3)$ belirtmektedir. Ankete yanıt verenler, kütüphanelerin kullanıcı kazanmak ve kütüphane kullanımını en üst düzeye çıkarmak için düzenledikleri etkinliklere genelde katılmadıklarını $(\% 68,9)$ dile getirmişlerdir. Araştırmada ayrıca, kullanıcı memnuniyetini arttırmak için kütüphanenin yeterli düzeyde çalıştığını düşünenlerin oranının \%42,2 ve kısmen yeterli olduğunu düşünenlerin oranının ise, \%38,9 olduğu ve bu oranın kullanıcı sayısının büyük bir çoğunluğuna karşılık geldiği belirtilmektedir.

Öndoğan (2010), Selçuk Üniversitesi Merkez Kütüphanesi'nde yürütülen halkla ilişkiler faaliyetlerinin kullanıcı memnuniyeti üzerine etkisini ele aldığı çalışmada; kullanıcıların fiziksel ve hizmet ögelerine ilişkin halkla ilişkiler çalışmalarından büyük oranda memnuniyet duyduklarını ancak, müşteri ilişkilerini geliştirmeye yönelik olarak kurum dışında yürütülen halkla ilişkiler çalışmalarından memnun olmadıklarını belirtmektedir.

Çalışmalarında kütüphanelerde halkla ilişkiler, TKY ve iç-dış müşteri memnuniyeti üzerine yoğunlaşan Yılmaz (2004a, s. 285) da bir çalışmasında, üniversite kütüphanelerinde müşteri merkezli yapılanma ve personel memnuniyeti konusunu incelemektedir. Yazara göre, kütüphane çalışanları, kendilerinin merkezi bir konumda olmadığını düşünmekte ve bu yüzden de yönetim, özlük hakları ve fiziksel ortam gibi çalışma yaşamına ilişkin ögelerden memnuniyetsizlik duymaktadır. Yine çalışanların büyük bir çoğunluğu, öneri ve şikâyetlerinin kütüphane yönetimi tarafından dikkate alınmadığı, iletişim kanallarının etkin çalışmadığı ve bu durumun da güdülenmelerini olumsuz yönde etkilediği görüşündedir.

\section{Erasmus Öğrenci ve Personel Hareketliliğinde Anadolu Üniversitesinin Rolü}

Erasmus, her yıl yaklaşık 200 bin öğrenciye yurt dışında çalışma ve eğitim görme fırsatı veren ve yaşam boyu öğrenmede AB'nin amiral gemisi olan bir programdır. Program'ın temel içeriğini, belirli anlaşmalar doğrultusunda öğrencilerin ve öğretim elemanlarının karşılıklı değişimi oluşturmaktadır. Erasmus Programı́ndan 25 yıl içinde yaklaşık üç milyon yükseköğretim öğrencisi yararlanmıştır (Özler, 2012).

Erasmus Programı́nın faaliyet alanlarına ilişkin eylem planları; öğrenci değişimi, akademisyen değişimi, karşılıklı değişimin örgütlenmesi, ortak program (müfredat) geliştirme projeleri, yoğun programlar, akademik uzmanlık ağları, Avrupa Kredi Transfer Sistemi ve Erasmus dil kurslarından oluşmaktadır (İşeri, 2005, ss. 64-73). Programa; Almanya, Avusturya, Belçika, Birleşik Krallık, Bulgaristan, Çek Cumhuriyeti, Danimarka, Estonya, Finlandiya, Fransa, Güney Kıbrıs Rum Kesimi, Hollanda, İrlanda, İspanya, İsveç, İtalya, Letonya, Litvanya, Lüksemburg, Macaristan, Malta, Polonya, Portekiz, Romanya, Slovak Cumhuriyeti, Slovenya ve Yunanistan'dan oluşan 27 AB üyesi ülke; İzlanda, Lihtenştayn ve Norveç ve AB'ye üye olmaya aday ülkeler arasında olan Türkiye (2004) yükseköğretim kurumları dahildir (Erasmus Hakkında, 2012). 
Tablo I'den de izlenebileceği gibi; Erasmus değişim programı kapsamında, 20042005 akademik yılından itibaren, öğrenci ve personeline yurt dışında eğitim olanağı sunan Anadolu Üniversitesi, bu alanda 2010-2011 akademik yılı itibariyle toplamda 4060 öğrenci ve öğretim elemanına yurtdışı hareketlilik olanağı sağlamıştır. 2004-2005 ve 2010-2011 dönemlerinde öğrenci değişimi çerçevesinde giden öğrenci sayısı 1904, gelen öğrenci sayısı ise 766 'dır. Aynı dönemlerde staj kapsamında giden öğrenci sayısı 274, buna karşılık gelen öğrenci sayısı 4 olmuştur. Yine aynı dönemlerde eğitim ve değişim kapsamında giden personel sayısı toplamda 744 iken, gelen kişi sayısı 363'tür. Üniversitenin ikili anlaşmalar çerçevesinde 155 üniversiteyle iş birliği bulunmaktadır'.

Tablo I. Anadolu Üniversitesi Erasmus Programı Verileri²

\begin{tabular}{|c|c|c|c|c|c|c|c|c|}
\hline \multicolumn{9}{|c|}{ ANADOLU ÜNIVERSITESI DEĞişiM PROGRAMLARI (ERASMUS) isTATiSTiĞi } \\
\hline \multirow[t]{2}{*}{ Akademik Yıl } & \multicolumn{2}{|c|}{ Öğrenci Değişimi } & \multicolumn{2}{|c|}{$\begin{array}{l}\text { Öğrenci Staj } \\
\text { Hareketliliği }\end{array}$} & \multicolumn{2}{|c|}{$\begin{array}{c}\text { Personel Eğitimi } \\
\text { Hareketliliği }\end{array}$} & \multicolumn{2}{|c|}{$\begin{array}{c}\text { Öğretim Elemanı } \\
\text { Değişimi }\end{array}$} \\
\hline & Giden & Gelen & Giden & Gelen & Giden & Gelen & Giden & Gelen \\
\hline 2004-2005 & 68 & 8 & - & - & - & - & 33 & 16 \\
\hline 2005-2006 & 185 & 45 & - & - & - & - & 40 & 22 \\
\hline 2006-2007 & 328 & 85 & - & - & - & - & 119 & 56 \\
\hline $2007-2008$ & 297 & 136 & 59 & 1 & 42 & - & 195 & 74 \\
\hline 2008-2009 & 307 & 172 & 86 & - & 34 & - & 64 & 95 \\
\hline 2009-2010 & 342 & 165 & 57 & 1 & 19 & - & 83 & 55 \\
\hline 2010-2011 & 377 & 155 & 77 & 2 & 25 & - & 90 & 45 \\
\hline $2011-2012^{3}$ & 440 & 148 & 100 & 6 & 25 & - & 96 & 37 \\
\hline $2012-2013^{4}$ & 232 & 106 & 145 & 1 & - & & - & 4 \\
\hline Toplam & 2576 & 1020 & 524 & 11 & 145 & - & 720 & 404 \\
\hline
\end{tabular}

Anadolu Üniversitesi, örgün eğitime kayıtlı 26.000 öğrenci ve uzaktan eğitime kayıtlı yaklaşık 1,6 milyon öğrenciyle (2009-2010 dönemi rakamlarına göre) Türkiye'nin en büyük, uzaktan öğretim kapsamında da dünyanın en büyük yükseköğretim kurumları arasında yer almaktadır (Visakorpi, Lewis, Ufert ve Smith, 2010, s. 4). Tablo II'deki 20082009 akademik yılında Türkiye'de bulunan yükseköğretim kurumları Erasmus öğrenci hareketliliği rakamlarına bakıldığı zaman, Ege Üniversitesi'nin 442 öğrenciyle birinci sırada yer aldığı görülmektedir. Anadolu Üniversitesi 393 öğrenciyle ikinci, İstanbul Teknik Üniversitesi (iTÜ) (377 öğrenci) üçüncü, Sakarya Üniversitesi (352 öğrenci) dördüncü ve ODTÜ ise 341 öğrenciyle beşinci sırada yer almaktadır.

\footnotetext{
Ayrıntılı liste için bkz. Anlaşmalı üniversiteler, 2012.

AÜ Değişim Programları İstatistiği (2012) temel alınarak hazırlanmıştır.

2011-2012 Akademik Yılı değişimleri bazı birimlerde halen devam etmektedir.

2012-2013 Akademik Yılı güz dönemi başvuru rakamları verilmiştir.
} 
Tablo II. 2008-2009 Akademik Yılı Yükseköğretim Kurumları Erasmus Öğrenci Hareketliliği ${ }^{5}$

\begin{tabular}{llccc}
\hline & Üniversite (ilk 10) & Öğrenim & Staj & Toplam \\
\hline $\mathbf{1}$ & Ege Üniversitesi & 398 & 44 & 442 \\
$\mathbf{2}$ & Anadolu Üniversitesi & 307 & 86 & 393 \\
$\mathbf{3}$ & ITÜ & 377 & 0 & 377 \\
$\mathbf{4}$ & Sakarya Üniversitesi & 334 & 18 & 352 \\
$\mathbf{5}$ & ODTÜ & 293 & 48 & 341 \\
$\mathbf{6}$ & Selçuk Üniversitesi & 302 & 12 & 314 \\
$\mathbf{7}$ & Ankara Üniversitesi & 224 & 88 & 312 \\
$\mathbf{8}$ & Hacettepe Üniversitesi & 278 & 31 & 309 \\
$\mathbf{9}$ & Yıldız Teknik Üniversitesi & 292 & 0 & 292 \\
$\mathbf{1 0}$ & Uludağ Üniversitesi & 274 & 0 & 274 \\
\hline
\end{tabular}

Anadolu Üniversitesi'nin uluslararası stratejisi, öğrenci ve öğretim elemanı hareketliliğini sağlamak için daha ileri kurumsal bağlantıların kurulmasına olanak sağlamak ve mevcut bilimsel araştırma etkinliklerini arttırmaktır. Bu strateji çerçevesinde Üniversite, Avrupa boyutunu uluslararası politikasının büyük bir bölümü olarak kabul etmektedir. Bu bağlamda Avrupa üniversiteleri ile ortak çalışma ve tüm Avrupa eğitim programlarına katılma yolunda Üniversite'nin tüm birimlerinde gerekli düzenlemeler yapılarak, öğrenci ve akademik personel, tanıtım seminerleri araclığıyla, Erasmus ve diğer programlar çerçevesinde bilgilendirilmektedir (http://www.uib.anadolu.edu.tr/ index.php? lang=tr\&mn=f7177163c833dff4b38fc8d2872f1ec6).

\section{Anadolu Üniversitesi Kütüphanesi}

1958 yılında Eskişehir İktisadi ve Ticari İlimler Akademisi'nin kurulmasıyla birlikte oluşturulan Kütüphane, 124 sayılı Kanun Hükmündeki Kararname'nin 33. Maddesinde belirtilen görevleri, 9 Haziran 1980 tarih ve 17012 sayılı Resmi Gazete'de yayımlanarak yürürlüğe giren yönetmelik çerçevesinde yürütmektedir (Tarihçe... 2012).

1994 yılı Mayıs ayında Yunus Emre Kampüsü'ndeki yeni binasına taşınan Kütüphane, kurulduğu günden itibaren her zaman kullanıcı memnuniyetini en üst düzeyde tutmayı hedefleyerek hizmetlerini yürütmektedir. Bölgede etkin bir araştırma merkezi konumunda olan Anadolu Üniversitesi Kütüphanesi sadece kendi öğrenci, öğretim elemanı ve çalışanlarına değil, aynı zamanda Eskişehir'de bulunan Osmangazi Üniversitesi öğrenci ve öğretim elemanlarına, şehir halkının tamamına ve civar şehirlerdeki araştırmacılara da hizmet vermektedir.

5 Erasmus: Yayınlar ve İstatistikler. (2010) temel alınarak hazırlanmıştır. 
1,000 kişilik oturma kapasitesine sahip Kütüphane binasının kapladığı toplam alan $12.330 \mathrm{~m}^{2}$ dir. Kütüphane, 2012 yılı sonu itibarıyla, uzman, genel idari hizmetler, yardımcı hizmetler, daimi işçi ve şirket işçisi kadrolarında 34 personel ve 37 yarı zamanlı öğrenciyle hizmet vermektedir. Kütüphane bu personel ile, eğitim ve öğretim döneminde hafta içi her gün 08:30-22:00, cumartesi günleri 09:00-21:00 ve pazar günleri ise; 12:00-19:30 saatleri arasında hizmet vermektedir. Yaz dönemi kütüphane çalışma saatleri ise; hafta içi her gün 08:30-18:00 arasıdır. Bu dönemde kütüphane hafta sonlarında hizmet vermemektedir.

Kütüphane dermesi, basılı ve elektronik kaynaklar bakımından oldukça zengindir. 2012 yılı sonu itibarıyla, basılı koleksiyonda yaklaşık olarak 276,000 kitap bulunmaktadır. Bununyanı sıra, elektronik olarak60 adet veri tabanına erişim sağlanmaktadır. Kütüphane dermesinin kaynak türlerine göre dağılımı Tablo III'de verilmektedir (Tarihçe..., 2012).

Tablo III. Dermenin Yayın Türlerine Göre Dağılımı

\begin{tabular}{lrrr}
\hline Tür & Adet & Tür & Adet \\
\hline Kitap & 275,679 & Proje & 595 \\
E-Kitap & 93,475 & Yazma Eser & 18 \\
Aktif Dergi Aboneliği & 882 & CD-ROM & 5.054 \\
E-Dergi & 45,360 & Slayt & 259 \\
Dergi (ciltli) & 40,000 & Ses Kaydı & 2,846 \\
Tez & 5,516 & Video Kaset & 348 \\
Müzik notası & 2,299 & Plak & 5 \\
Mikroform & 6,802 & VCD & 227 \\
Mikroform-Rulo & 1,167 & DVD & 679 \\
Rapor & 814 & Veri Tabanı & 60 \\
\hline
\end{tabular}

Anadolu Üniversitesi personeli ve öğrencileri üniversite kimlikleriyle ödünç kaynak alabilirler. Anadolu Üniversitesi personeli olmayan kullanıcılar ise; başvuruları Rektörlük tarafından onaylandıktan sonra “Dış Kullanıcı" statüsünde ödünç kaynak alabilmektedir. Danışma kaynakları, süreli yayınların ciltlenmemiş sayıları, yayımlanmamış tezler ve ayrık kitaplar dışındaki tüm yayınlar belirlenen kurallar çerçevesinde ödünç verilmektedir.

Akademisyenler bir defada 20 yayını bir ay süreyle; öğrenciler, aynı anda 7 yayını 15 gün süreyle; dış kullanıcı statüsündeki kullanıcılar ise, 2 adet yayını 15 günlüğüne ödünç alabilmektedir.

\section{Amaç, Kapsam ve Yöntem}

Araştırmanın temel amacı, Anadolu Üniversitesi'ne yurt dışından Erasmus Programı ile gelen öğrencilerin kütüphane memnuniyet düzeylerini belirlemek ve bunları geldikleri 
üniversite kütüphanesinde algıladıkları memnuniyet düzeyleri ile karşılaştırmaktır. Araştırma evrenini, 2010-2011 öğretim yılında öğrenci değişimi yoluyla Anadolu Üniversitesi'ne gelen 155 yabancı öğrenci oluşturmaktadır. 74 öğrenci üzerinde gerçekleştirilmiş olan araştırmanın verileri 15 Mayıs-31 Temmuz 2010 tarihleri arasında toplanmıştır. Anketler, çalışma amacının belirtilmesinin ardından araştırmaya katılmaya gönüllü 74 öğrenciye dağıtılmış ve kişi yönelimli (self-administered) teknik ile elde edilmiştir. Ankette yer alan 10 soruyu katılımcıların \%58'i yanıtlamış olup, bu durum "Bulgular ve Yorum" bölümünde yer alan tablolarda ve açıklamalarda vurgulanmıştır.

Anket soruları, ana dili İngilizce olan bir öğretim elemanından yardım alınarak, İngilizceye çevrilmiştir. Ankette kullanılan ifadelerin anlaşıırlığını sınamak amacıyla, Anadolu Üniversitesi Eğitim Fakültesi İngilizce Öğretmenliği Bölümü 4. sınıfa devam eden 10 öğrenci üzerinde pilot bir çalışma yapılmış ve alınan geribildirim doğrultusunda ankette gerekli düzeltmeler yapılarak son biçimi verilmiştir.

Anket formu 2 bölüm halinde tasarlanmıştır. Birinci bölüm, öğrencilerin demografik yapılarına ilişkin 7 sorudan oluşmaktadır. Anketin ikinci bölümü ise, öğrencilerin memnuniyet düzeylerinin belirlenmesine yönelik 14 ifadeden oluşmaktadır. İkinci bölümdeki ifadeler beşli Likert Ölçeği ile değerlendirilmiştir.

Çalışmada, araştırma amacına uygun olarak betimsel ve bağıntısal araştırma modeli kullanılmıştır. Elde edilen verilerin analizinde Sosyal Bilimler için üretilen ve işletme, ekonomi, sosyoloji gibi birçok alanda yaygın olarak kullanılan IBM SPSS Statistics 19 programı tercih edilmiştir. Yüzdeler ankete yanıt veren toplam kişi sayısı üzerinden hesaplanmıştır. Ayrıca ki-kare testi kullanılarak "cinsiyet", "öğrencilerin geldiği ülke", "kütüphanede kalınan süre" ve "kütüphane kullanım biçimi" ile "memnuniyet düzeyi" arasındaki ilişkisi irdelenmeye çalışılmıştır.

\section{Bulgular ve Yorum}

\section{Araştırma Katılımcılarına İlişkin Özellikler}

Araştırma grubundaki 74 öğrenciden 46'sı kadın, 28'i ise erkektir. Öğrencilerin 50'si "1823 ", 23'ü "24-29" ve 1'i ise "30-35 yaş grubunda bulunmaktadır. Verilen yanıtlara göre; öğrencilerden $16^{\prime}$ sı iktisadi ve idari bilimler, $15^{\prime} \mathrm{i}$ iletişim bilimleri, 13'ü turizm, 7'şer öğrenci edebiyat, mühendislik ve güzel sanatlar, $5^{\prime} i$ hukuk, $3^{\prime}$ ü sivil havacılık ve $1^{\prime} i$ ise eğitim bilimleri alanında öğrenim görmektedir.

Araştırmaya katılan öğrencilerin büyük bir çoğunluğu (23 öğrenci) Anadolu Üniversite'sine Polonya'dan gelmektedir. Bunu İspanya (13 öğrenci), Litvanya (10 öğrenci), Çek Cumhuriyeti (5 öğrenci), Almanya (4 öğrenci), Hollanda (3 öğrenci), 2'şer öğrenciyle Kırgızistan, Özbekistan, Kazakistan, Estonya, Slovakya, Fransa ve 1'er öğrenciyle Norveç, Italya, Kanada ve Romanya takip etmektedir. 
Katılımcıların Anadolu Üniversitesi'ni tercih etme nedenleri değerlendirildiğinde; "yabancı bir ülke deneyimi kazanmak" amacıyla gelen öğrencilerin oranı $(\% 66,2)$ en yüksek olup, bunu "arkadaşlarının önerisiyle" (\%19), "öğrenim alanında iyi bir eğitim vermesi" (\%4), "hocasının yönlendirmesiyle" $(\% 5,4)$ ve "diğer nedenlerle" $(\% 5,4)$ yanıtları izlemektedir.

Anadolu Üniversitesi'nin kurum olarak, genelde öğrenciye yaklaşımı konusu oranları irdelendiğinde; \%54,8 ile "iyi", \%34,2 ile "mükemmel" ve \%11 ile "orta" olarak değerlendirildiği ve buna ek olarak, öğrencilerin büyük bir oranla $(\% 78,1)$ Erasmus Kulübü'nün düzenlediği üniversite tanıtım gezisine katıldığı görülmektedir.

\section{Katılımcıların Kütüphane Hizmetlerine Illişkin Görüşleri}

Katılımcılara yöneltilen, “Erasmus Kulübü'nün düzenlediği üniversite tanıtım gezisi kapsamında kütüphaneye geldiniz mi?" sorusuna, \%69,9'u "evet" yanıtını vermiştir. Bu öğrencilerden \%87,8'i "kütüphane tanıtımı için ayrılan süre" ve "tanıtım ekibinin yeterliliği" konularında olumlu görüş bildirmiştir.

Tablo IV. Katılımcıların Kütüphaneyi Kullanma Sıklıkları (N=74)

\begin{tabular}{lrr}
\hline Kütüphane Kullanım Sıklığı & Sıklık & \% \\
\hline Hiç & 26 & 35,1 \\
Düzensiz & 35 & 47,3 \\
Haftada 1 kez & 4 & 5,4 \\
Haftada birkaç kez & 5 & 6,8 \\
Her gün & 4 & 5,4 \\
\hline Toplam & $\mathbf{7 4}$ & $\mathbf{1 0 0}$ \\
\hline
\end{tabular}

Tablo IV'de görüldüğü gibi, ankete katılan öğrencilerin kütüphaneyi kullanma eğilimleri oldukça düşüktür.

Tablo V. Katılımcıların Kütüphaneyi Kullanma Amaçları (N=44)

\begin{tabular}{lrr}
\hline Kütüphane Kullanım Amaçları & Sıklık & \% \\
\hline Serbest zamanı değerlendirmek & 1 & 2,3 \\
Ders çalışmak & 15 & 34,1 \\
Ödünç kitap almak & 10 & 22,7 \\
Araştırma yapmak & 16 & 36,4 \\
Diğer & 2 & 4,5 \\
\hline Toplam & $\mathbf{4 4}$ & $\mathbf{1 0 0}$ \\
\hline
\end{tabular}

Katılımcıların 30'u kütüphaneyi kullanma amaçlarına yönelik soruya yanıt vermemiştir. Ankete yanıt veren öğrencilerin kütüphaneyi kullanma amaçları; araştırma 
yapmak $(\% 36,4)$, ders çalışmak $(\% 34,1)$ ve ödünç kitap almak $(\% 22,7)$ üzerinde yoğunlaşmaktadır (Tablo V).

Tablo VI. Katılımcıların Kütüphanede Kalma Süreleri ( $N=43)$

\begin{tabular}{lrr}
\hline Kütüphane Kullanım Süreleri & Sıklık & \% \\
\hline Yarım saatten az & 5 & 11,6 \\
1-3 saat arası & 19 & 44,2 \\
3 saatten fazla & - & - \\
Ödünç işlemi tamamlanıncaya & & 14,0 \\
kadar & 6 & 30,2 \\
Araştırma bitirilene kadar & 13 & $\mathbf{1 0 0}$ \\
\hline Toplam & $\mathbf{4 3}$ & $\mathbf{1 0 0}$ \\
\hline
\end{tabular}

Ankette yer alan "kütüphanede genellikle ne kadar süre kalıyorsunuz" sorusunu 43 öğrenci yanıtlamış geri kalan 31 öğrenci ise boş bırakmıştır. Kütüphane kullanım süreleri değerlendirildiğinde; öğrencilerin büyük bir çoğunluğununun kütüphane kullanım sürelerinin 1 ile 3 saat aralığında olduğu görülmektedir (Tablo VI).

Tablo VII. Kütüphanenin Derme (Koleksiyon) Açısından Değerlendirilmesi (N=44)

\begin{tabular}{lrr}
\hline Dermedeki Materyal Sayısı ve Çeşidi & Sıklık & \% \\
\hline Zayıf & 1 & 2,3 \\
Orta & 3 & 6,8 \\
lyi & 22 & 50,0 \\
Mükemmel & 14 & 31,9 \\
Fikrim yok & 4 & 9,0 \\
\hline Toplam & $\mathbf{4 4}$ & $\mathbf{1 0 0}$ \\
\hline
\end{tabular}

Katılımcıların 30'u kütüphane dermesinin özelliklerine ilişkin soruya yanıt vermemiştir. Soruyu yanıtlayan öğrencilerin büyük bir çoğunluğu kütüphane dermesinin iyi düzeyde olduğunu belirtmektedir (Tablo VII).

Tablo VıII. Kütüphanenin Fiziksel Özelliklerinden Isıtma, Havalandırma, Aydınlatma ve Kullanım Alanı Genişliği Ögelerinin Değerlendirilmesi ( $\mathrm{N}=44)$

\begin{tabular}{|c|c|c|c|c|c|c|c|c|c|c|}
\hline \multirow{2}{*}{ Fiziksel Özellikler } & \multicolumn{2}{|c|}{ Fikrim Yok } & \multicolumn{2}{|c|}{ Zayıf } & \multicolumn{2}{|c|}{ Orta } & \multicolumn{2}{|c|}{ İyi } & \multicolumn{2}{|c|}{ Mükemmel } \\
\hline & $\mathbf{n}$ & $\%$ & $\mathbf{n}$ & $\%$ & $\mathbf{n}$ & $\%$ & $\mathbf{n}$ & $\%$ & $\mathbf{n}$ & $\%$ \\
\hline Isıtma & 3 & 6,8 & 1 & 2,2 & 4 & 9,4 & 17 & 38,5 & 19 & 43,1 \\
\hline Havalandırma & & & 3 & 6,8 & 13 & 29,5 & 15 & 34,2 & 13 & 29,5 \\
\hline Aydınlatma & 1 & 2,3 & 2 & 4,5 & 4 & 9,1 & 25 & 56,8 & 12 & 27,3 \\
\hline Kullanım Alanı Genişliği & 1 & 2,3 & & & 8 & 18,2 & 18 & 40,9 & 17 & 38,6 \\
\hline
\end{tabular}


Araştırmaya katılan öğrencilerden 44'ü kütüphanenin fiziksel özelliklerinden ısıtma, havalandırma, aydınlatma ve kullanım alanı genişliği hakkında görüşlerini bildirmiştir. Tablo VIII'de görüldüğü gibi, öğrenciler, kütüphanenin ısıtma sistemini \%81,6; havalandırma sistemini \%63,7; aydınlatma sistemini \%84,1 ve kullanım alanı genişliğini ise $\% 79,5$ oranlarında olumlu (mükemmel ve iyi) olarak değerlendirmiştir.

Tablo IX. Kütüphanenin Fiziksel Özelliklerinden Mobilyalar, Yönlendirme Bilgileri, Bireysel Çalışma Odaları ve Oturma Kapasitesi Ögelerinin Değerlendirilmesi $(\mathrm{N}=44)$

\begin{tabular}{|c|c|c|c|c|c|c|c|c|c|c|}
\hline \multirow{2}{*}{ Fiziksel Özellikler } & \multicolumn{2}{|c|}{ Fikrim Yok } & \multicolumn{2}{|c|}{ Zayıf } & \multicolumn{2}{|c|}{ Orta } & \multicolumn{2}{|c|}{ İyi } & \multicolumn{2}{|c|}{ Mükemmel } \\
\hline & $\mathbf{n}$ & $\%$ & $\mathbf{n}$ & $\%$ & $\mathbf{n}$ & $\%$ & $\mathbf{n}$ & $\%$ & $\mathbf{n}$ & $\%$ \\
\hline Mobilyalar & & & 3 & 6,8 & 8 & 18,2 & 18 & 40,9 & 15 & 34,1 \\
\hline $\begin{array}{l}\text { Kütüphane-içi } \\
\text { Yönlendirme Bilgileri }\end{array}$ & 1 & 2,3 & 2 & 4,5 & 12 & 27,3 & 15 & 34,1 & 14 & 31,8 \\
\hline Bireysel Çalışma Odaları & 8 & 18,2 & 4 & 9,1 & 2 & 4,5 & 19 & 41,2 & 11 & 25,0 \\
\hline Oturma Kapasitesi & & & 2 & 4,5 & 6 & 13,6 & 21 & 47,8 & 15 & 34,1 \\
\hline
\end{tabular}

Kütüphanenin fiziksel özelliklerini (mobilya, kütüphane-içi yönlendirme bilgileri, bireysel çalışma odaları ve oturma kapasitesi) değerlendiren 44 öğrencinin büyük bir kısmı; mobilyaları (raf, masa, sandalye, oturma grubu), yönlendirme bilgilerini, bireysel çalışma odalarını ve oturma kapasitesini yeterli bulurken, bunun aksini düşünenlerin oranı ise oldukça düşüktür (Tablo IX).

Tablo X. Kütüphanenin Fiziksel Özelliklerinden Kullanıcı Bilgisayarları, Genel Temizlik, WC/Lavaboların Temizliği ve Sessizlik Ögelerinin Değerlendirilmesi ( $N=44)$

\begin{tabular}{|c|c|c|c|c|c|c|c|c|c|c|}
\hline \multirow{2}{*}{ Fiziksel Özellikler } & \multicolumn{2}{|c|}{ Fikrim Yok } & \multicolumn{2}{|c|}{ Zayıf } & \multicolumn{2}{|c|}{ Orta } & \multicolumn{2}{|c|}{ İyi } & \multicolumn{2}{|c|}{ Mükemmel } \\
\hline & $\mathbf{n}$ & $\%$ & $\mathbf{n}$ & $\%$ & $\mathbf{n}$ & $\%$ & $\mathbf{n}$ & $\%$ & $\mathbf{n}$ & $\%$ \\
\hline Kullanıcı Bilgisayarları & 9 & 20,5 & 3 & 6,8 & 7 & 15,9 & 18 & 40,9 & 7 & 15,9 \\
\hline Genel Temizlik & 4 & 9,1 & 3 & 6,8 & 4 & 9,1 & 23 & 52,3 & 10 & 22,7 \\
\hline $\begin{array}{l}\text { WC/ Lavaboların } \\
\text { Temizliği }\end{array}$ & 7 & 15,9 & 6 & 13,6 & 7 & 15,9 & 18 & 41,0 & 6 & 13,6 \\
\hline Sessizlik & & & 4 & 9,1 & 11 & 25,0 & 18 & 40,9 & 11 & 25,0 \\
\hline
\end{tabular}

Araştırmaya katılan öğrencilerden 44'ü kütüphanenin fiziksel özelliklerinden kullanıcı bilgisayarları, genel temizlik, WC/lavaboların temizliği ve sessizlik durumu hakkında görüşlerini bildirmiştir. Tablo X'da görüldüğü gibi; öğrenciler, kütüphanenin sessizlik durumunu en yüksek oranla $(\% 65,9)$ olumlu (mükemmel ve iyi) bulurken, bunu $\% 75,0^{\prime}$ lik bir oranla genel temizlik, $\% 56,8^{\prime}$ lik bir oranla bilgisayar kapasitesi ve $\% 54,6^{\prime}$ lık bir oranla WC/lavaboların temizliği izlemektedir. 
Tablo XI. Aranılan Bilgi Kaynağına Ulaşmak İçin Seçilen Yöntem (N=44)

\begin{tabular}{lrc}
\hline Materyale Ulaşmak İçin Seçilen Yöntem & Sıklık & \% \\
\hline Katalog taraması yapmak & 7 & 15,9 \\
Görevlilerden yardım almak & 5 & 11,4 \\
Raflardan arayarak & 17 & 38,6 \\
Arkadaşların deneyimlerinden yararlanarak & 9 & 20,5 \\
Yukarıdakilerden hepsini kullanarak & 6 & 13,6 \\
\hline Toplam & $\mathbf{4 4}$ & $\mathbf{1 0 0}$ \\
\hline
\end{tabular}

Araştırmaya katılan öğrencilerin büyük bir bölümü $(\% 38,6)$, aradıkları bilgi kaynaklarına, rafları tarayarak ulaşmaktadır (Tablo XI).

Tablo XII. Kütüphanede Sunulan Bilgi ve Belge Hizmetlerinin Genel Değerlendirilmesi $(\mathrm{N}=44)$

\begin{tabular}{|c|c|c|c|c|c|c|c|c|c|c|}
\hline \multirow{2}{*}{ Bilgi ve Belge Hizmetleri } & \multicolumn{2}{|c|}{$\begin{array}{c}\text { Fikrim } \\
\text { Yok }\end{array}$} & \multicolumn{2}{|c|}{ Zayıf } & \multicolumn{2}{|c|}{ Orta } & \multicolumn{2}{|c|}{ İyi } & \multicolumn{2}{|c|}{ Mükemmel } \\
\hline & $\mathbf{n}$ & $\%$ & $\mathbf{n}$ & $\%$ & $\mathbf{n}$ & $\%$ & $\mathbf{n}$ & $\%$ & $\mathbf{n}$ & $\%$ \\
\hline $\begin{array}{l}\text { Ödünç Verme/ Materyal Ayırtma } \\
\text { (Rezerve) Hizmetleri }\end{array}$ & 6 & 13,6 & 2 & 4,5 & 3 & 6,8 & 21 & 47,8 & 12 & 27,3 \\
\hline $\begin{array}{l}\text { Geleneksel ve Elektronik Kaynaklara } \\
\text { Erişim ve Yönlendirme }\end{array}$ & 7 & 15,9 & & & 8 & 18,2 & 19 & 43,2 & 10 & 22,7 \\
\hline Kablosuz Internet Ağı (Wi-Fi) Hizmeti & 4 & 9,0 & 1 & 2,3 & 12 & 27,3 & 14 & 31,8 & 13 & 29,6 \\
\hline $\begin{array}{l}\text { Kampus Dışından Elektronik } \\
\text { Kaynaklara Erişim Hizmeti }\end{array}$ & 9 & 20,5 & 3 & 6,8 & 7 & 15,9 & 19 & 43,2 & 6 & 13,6 \\
\hline $\begin{array}{l}\text { Otomatik Ödünç Alma/Verme } \\
\text { Makineleri (Self-Check) }\end{array}$ & 11 & 25,0 & 2 & 4,5 & 5 & 11,4 & 18 & 40,9 & 8 & 18,2 \\
\hline Fotokopi Hizmetleri & 7 & 15,9 & & & 4 & 9,1 & 14 & 31,8 & 19 & 43,2 \\
\hline
\end{tabular}

Kütüphanede sunulan bilgi ve belge hizmetlerinin genel bir değerlendirmesi yapıldığında; soruya yanıt veren 44 öğrenciden 33'ü $(\% 75,1)$ "ödünç ve materyal ayırtma" ve "fotokopi" hizmetlerini (\%75) diğer hizmetlere oranla daha başarılı bulmaktadır. Bunu; 29 kişi ile $(\% 65,9)$ "geleneksel ve elektronik kaynaklara erişim ve yönlendirme" hizmeti, 27 kişi ile $(\% 61,4)$ "kablosuz internet ağı" hizmeti, 26 kişi ile $(\% 59,1)$ "otomatik ödünç alma/verme (self-check)" hizmeti ve 25 kişi $(\% 56,8)$ ile de "kampüs dışından elektronik kaynaklara erişim" hizmeti izlemektedir (Tablo XII). 
Tablo XIII. Kütüphane Otomasyon Programının Değerlendirilmesi (N=44)

\begin{tabular}{lcccccccccr}
\hline \multirow{2}{*}{\begin{tabular}{l} 
Otomasyon Programı \\
\multicolumn{1}{c}{ Özellikleri }
\end{tabular}} & \multicolumn{1}{c}{ Fikrim Yok } & \multicolumn{2}{c}{ Zayıf } & \multicolumn{2}{c}{ Orta } & \multicolumn{2}{c}{ İyi } & \multicolumn{2}{c}{ Mükemmel } \\
\cline { 2 - 12 } & $\mathbf{n}$ & $\%$ & $\mathbf{n}$ & $\%$ & $\mathbf{n}$ & $\%$ & $\mathbf{n}$ & $\%$ & $\mathbf{n}$ & $\%$ \\
\hline Etkin kullanılabilirlik & 4 & 9,1 & 1 & 2,3 & 2 & 4,5 & 21 & 47,7 & 16 & 36,4 \\
$\begin{array}{l}\text { Sorgulama seçeneklerinin } \\
\text { anlaşılabilirliği }\end{array}$ & 5 & 11,4 & & & 3 & 6,8 & 23 & 52,3 & 13 & 29,5 \\
Çalışma hızı & 4 & 9,1 & & & 6 & 13,6 & 20 & 45,5 & 14 & 31,8 \\
Arayüzünün kullanışlıı̆ı & 4 & 9,1 & 1 & 2,3 & 2 & 4,5 & 23 & 52,3 & 14 & 31,8 \\
\hline
\end{tabular}

Kütüphane otomasyon programının değerlendirilmesine yönelik soruya yanıt veren 44 öğrencinin \%84,1'i "etkin kullanılabilirliğini" ve "ara yüzünün kullanışlılığını" olumlu (mükemmel ve iyi) bulduklarını belirtmiştir (Tablo XIII). Bunu \%81,8 ile "sorgulama seçeneklerinin anlaşılabilirliği" ve \%77,3 ile "çalışma hızı" izlemektedir. Öğrenciler otomasyon programının etkin kullanılabilirliğinde ve ara yüzünün kullanışlılığında \%2,3'lük bir oranda sıkıntı yaşarken, sorgulama seçeneklerinin anlaşılabilirliğinde ve çalışma hızında herhangi bir sorunla karşılaşmamıştır (Tablo XIII).

Erasmus Programı kapsamında Anadolu Üniversitesi'ne gelen öğrencilere yöneltilen soruların bir bölümünde de, geldikleri üniversite kütüphaneleri ile Anadolu Üniversitesi Kütüphanesi'nin çeşitli açılardan kıyaslanması amaçlanmıştır.

Kıyaslama/Örnek edinme (benchmarking), müşterilere sunulan hizmeti geliştirmek için yararlanılan önemli yönetsel araçlardandır. Günümüz kütüphane yöneticilerinin yönettikleri örgütün bilgi sektöründeki durumunun ne olduğunu ve gelecekte nerelerde olacağını değerlendirmeleri için, strateji oluşturma ve uygulama düzeylerinde birçok başarım ölçütlerinin belirlenip, zaman içindeki gelişmelerin bunlara göre ölçülmesi gerekmektedir. Son zamanların en sık kullanılan başarım ölçütleri arasında; kullanıcı ve personele sunulan hizmetlerin hızı, soruların yanıtlanma hızı ve miktarı, bilginin güvenilirliği ile hizmetlerdeki sürekli iyileştirmeye eğilim ve istek örnek olarak verilebilir. Ancak bu başarım ölçütleri ve ölçümlerinin de dış çevre koşullarında yaşanan değişimlere ayak uydurmayı tam olarak sağladığı söylenemez. Bundan dolayı kütüphanelerde daha dinamik bir sistem arayışı söz konusu olacaktır. İşte bu arayışlar, "örnek edinme" uygulamalarını daha da vazgeçilmez kılmaktadır (Kurulgan, 2007, s.31, 44).

Buradan hareketle, araştırmaya katılan öğrencilere; Anadolu Üniversitesi Merkez Kütüphanesi ile geldikleri üniversitelerin kütüphanelerini "fiziksel özellikler", "verilen hizmetin niteliği", "personelin davranışı, bilgi ve becerisi" ve "kütüphanenin sahip olduğu basılı ve e-kaynakların nicelik ve niteliği" açılarından karşılaştırılmasına yönelik sorular hazırlanmıştır. Araştırmaya katılan 74 öğrenciden 44 'ü $(\% 59,4)$ bu sorulara yanıt vermiştir. 
Tablo XIV. Anadolu Üniversitesi ile Gelinen Üniversite Kütüphanesinin Fiziksel Özellikler, Verilen Hizmetin Niteliği, Personelin ve Dermenin Yeterliliği Açılarından Karşılaştırılması ( $\mathrm{N}=44)$

\begin{tabular}{|c|c|c|c|c|c|c|c|c|c|c|}
\hline \multirow{3}{*}{ Ölçütler } & \multicolumn{5}{|c|}{ Anadolu Üniversitesi Kütüphanesi } & \multicolumn{5}{|c|}{ Gelinen Üniversite Kütüphanesi } \\
\hline & 1 & 2 & 3 & 4 & 5 & 1 & 2 & 3 & 4 & 5 \\
\hline & $\mathbf{N}$ & $\mathbf{N}$ & $\mathbf{N}$ & $\mathbf{N}$ & $\mathbf{N}$ & $\mathbf{N}$ & $\mathbf{N}$ & $\mathbf{N}$ & $\mathbf{N}$ & $\mathbf{N}$ \\
\hline Fiziksel Özellikler & 4 & - & 9 & 18 & 13 & 4 & 4 & 9 & 16 & 11 \\
\hline Hizmetin Nicelik/Niteliği & - & 1 & 9 & 25 & 9 & 1 & 2 & 6 & 27 & 8 \\
\hline Personel Nicelik/Niteliği & 1 & 1 & 9 & 21 & 12 & 1 & 4 & 4 & 21 & 14 \\
\hline Dermenin Nicelik/Niteliği & 2 & 1 & 6 & 21 & 14 & 1 & 3 & 8 & 18 & 14 \\
\hline
\end{tabular}

N: Öğrenci Sayısı/Sıkık; ("1" Fikrim Yok, "2" Zayıf, "3" Orta, "4" lyi, "5" Mükemmel)

Anketin, “Anadolu Üniversitesi ile gelinen üniversite kütüphanesinin fiziksel özellikler, verilen hizmetin niteliği, personelin ve dermenin yeterliliği açılarından karşılaştııılması" bölümüne 44 öğrenci yanıt vermiştir. Tablo XIV'de; Anadolu Üniversitesi Merkez Kütüphanesi'nin fiziksel özelliklerinden memnun olan katılımcıların oranı ${ }^{6}(\% 70,5)$, kendi üniversite kütüphanelerinden memnun olanların oranına göre $(\% 61,4)$ daha yüksektir. Ancak hizmetin nicelik ve nitelik ölçütüne bakıldığı zaman memnun olan öğrenci oranı $(\% 77,2)$, geldikleri üniversitelerin kütüphanelerinden memnun olanların oranına göre $(\% 79,5)$ daha düşük olduğu görülmektedir. Personel nicelik/niteliği söz konusu olduğunda; öğrencilerin geldikleri üniversitelerin kütüphaneleri \%79,5'lik bir oranla Anadolu Üniversitesi Kütüphanesi'nden (\%75) daha başarılı bulunduğu görülmektedir. Kıyaslanan son ölçüt olan dermenin nicelik/niteliği açısından irdelendiğinde ise, Anadolu Üniversitesi Kütüphanesi'nin $(\% 79,5)$ diğer üniversite kütüphanelerine oranla $(\% 72,3)$ daha yetkin olduğu söylenebilir.

Tabloya bir başka açıdan bakıldığında ise; Anadolu Üniversitesi Kütüphanesi'nin hizmet, personel ve dermenin durumu açısından birer (toplamda 3) öğrencinin olumsuz görüşüne (zayıf) rastlanırken, diğer kütüphanelerde bu durum toplamda 9 öğrencinin olumsuz görüşüyle sonuçlanmaktadır. Yukarıdaki ölçütlere "fikrim yok" diyen öğrenci sayısı her iki kütüphanede de (7 öğrenci) eşittir.

Çalışmada ayrıca ki-kare testi kullanılarak, "cinsiyet", "öğrencilerin geldiği ülke", "kütüphanede kalınan süre", "kütüphane kullanım biçimi" ile "memnuniyet düzeyi" ilişkisi irdelendiğinde, değişkenler arasında anlamlı bir ilişkiye rastlanmamıştır.

\section{Sonuç ve Öneriler}

Bu bölümde, araştırma sonunda elde edilen bulgulara dayalı olarak geliştirilen sonuç ve öneriler yer almaktadır.

6 Oranlar, 5'li Likert Ölçeği'nin olumlu ifadelerini (4 ve 5) işaretleyen öğrencilerin sayısı toplanmış ve çıkan sonuç bu soruya yanıt veren toplam öğrenci sayısına bölünerek bulunmuştur. 


\section{Sonuç}

Rekabetin oldukça yoğun bir biçimde yaşandığı hizmet sektöründe sunulan hizmetin kalitesi, bu sektörde faaliyet gösteren örgütlerin değerlendirilmesinde önemli bir ölçüt olarak kabul edilmektedir. Nitekim günümüzde gerek kamu sektöründe ve gerekse özel sektörde yer alan tüm işletmeler gibi kütüphane örgütleri de; sundukları hizmetin kalitesini ölçmek durumundadır.

Bilindiği gibi üniversiteler, eğitim-araştırma gibi toplumsal kalkınmada oldukça önemli olan ve kütüphaneleri de bünyesinde barındıran hizmet kurumlarıdır. Önceleri "üniversitenin kalbi" olarak nitelendirilen üniversite kütüphaneleri, günümüz bilgi toplumunda, "üniversitenin beyni" konumuna gelmiştir (Kurulgan, 2004, s. 43). Üniversiteler açısından bu kadar önemli olan kütüphane örgütü, dış müşterilerinin (kullanıcılar) memnuniyet düzeylerini artırabilmek için, onların istek ve beklentilerini etkin bir biçimde karşılamak durumundadır. Bunun yolu da kullanıcıların iyi tanınmasından ve onların gereksinimlerinin iyi analiz edilmesinden geçer. Daha önce de belirtildiği gibi, kütüphane hizmetlerinin kullanıcıya dönük bir anlayışla planlanabilmesi; kullanıcı gereksinimlerinin ve kullanıcıların çeşitli kütüphane hizmetleri ile ilgili düşüncelerinin öğrenilmesi, kütüphanecilerle kullanıcıların çeşitli kademe ve koşullardaki iletişimi ile mümkündür. Kullanıcılarla etkin bir iletişim kurulmadan sağlanacak hizmetler, onları memnuniyetsizliğe hatta kütüphaneye karşı güven duymamaya itebilir. Üniversite kütüphaneleri ve kullanıcıları arasında başarılı bir iletişimin kurulması, güvenin ön planda olduğu iki yönlü, açık ve etkin bir iletişimin sağlanmasına bağlıdır. Bu durum kütüphanecilerin, kullanıcılar ve kütüphanenin karşılıklı çıkarlarını dikkate alarak kullanıcı beklentilerine odaklanmalarına yardımcı olur (Karakaş, 1999a, s. 64).

Bu bilgilerden hareketle araştırmanın iki boyutu bulunmaktadır. Birincisi Erasmus değişim programı kapsamında ele alınan yükseköğretim öğrencilerinin Anadolu Üniversitesi Merkez Kütüphanesi ortam ve hizmetlerine ilişkin memnuniyet durumlarını saptamak; ikincisi ise, Anadolu Üniversitesi Merkez Kütüphanesi hizmetlerine dönük olarak algıladıkları memnuniyet düzeyleri ile geldikleri üniversitenin kütüphanesine ilişskin memnuniyet durumlarını karşılaştırmalı olarak belirlemektir.

Araştırmanın birinci boyutuna ilişkin sonuçlar aşağıdaki biçimde sıralanabilir:

$\diamond$ Araştırmaya katılan öğrenciler arasında çoğunluğu $(\% 62,1)$ bayan öğrenciler oluşturmaktadır. Öğrencilerin öğrenim alanlarına bakıldığı zaman, ilk sıralarda ekonomi, yönetim bilimleri ve turizmin geldiği görülmektedir. Öğrencilerin büyük bir çoğunluğu (\%31) Polonya'da öğrenim görmektedir.

$\diamond$ Öğrencilerin büyük bir çoğunluğu $(\% 66,2)$, Anadolu Üniversitesi'ne, yabancı bir ülke deneyimi kazanmak amacıyla gelmiştir.

$\diamond$ Araştırmaya katılan öğrencilerin büyük bir bölümü $(\% 69,9)$, Erasmus Kulübü'nün düzenlediği kütüphane gezisine katılmıştır. 
$\checkmark$ Katılımcıların, kütüphaneyi yüksek oranlarda, düzensiz kullandıkları $(\% 47,3)$ ve hiç kullanmadıkları $(\% 35,1)$ göz önünde bulundurulursa; kullanma sıklıklarının iyi bir düzeyde olmadığı söylenebilir. Bu durum araştırmada ulaşılmak istenilen memnuniyet bulgularını olumsuz yönde etkilemektedir. Çünkü kütüphaneyi gerçek anlamda kullanan denek sayısı oldukça sınırlıdır ve güçlü bir yorum yapılmasına engel teşkil etmektedir.

$\diamond$ Araştırmaya katılan öğrencilerden 44'ü kütüphaneyi -genelde- araştırma yapmak ve ders çalışmak amacıyla kullandıklarını belirtmiş 30 öğrenci ise bu soruyu yanıtlamamıştır. Öğrencilerin kütüphane kullanma süreleri -genellikle- 1 ile 3 saat arasında değişmektedir.

$\diamond$ Dermedeki kaynak sayısı ve çeşitliliğini, 44 öğrenciden 36'sı $(\% 81,9)$ olumlu olarak değerlendirmiştir. Bu ölçüte göre kullanıcı memnuniyet durumu oldukça iyi görünmektedir.

$\diamond$ Katılımcıların büyük bir çoğunluğu ısıtma, havalandırma, aydınlatma, kullanım alanı genişliği, mobilyalar, kütüphane-içi yönlendirme bilgileri, bireysel çalışma odaları ve oturma kapasitesi, kullanıc bilgisayarları, genel temizlik ve sessizlik ölçütleri temelinde kütüphanenin fiziksel özelliklerinin uygun olduğunu belirtmiştir ( $\mathrm{Bu}$ soruya 44 öğrenci yanıt vermiştir).

$\diamond$ Öğrenciler aradıkları bilgi kaynaklarına, genelde, raf aralarında dolaşarak ulaşmaktadır. Katılımcıların yaklaşık \%14'ü ise, katalog taraması yapmak, görevlilerden ve arkadaşlarından destek almak ve raflardan aramak gibi yöntemleri bir arada kullanabilmektedir. Soruya yanıt veren öğrencilerin küçük bir oranı $(\% 11,4)$ dışında kalanlar, bilgi kaynaklarına ulaşırken görevlilerden yardım almayı tercih etmemektedir (Bu soruyu 44 öğrenci yanıtlamıştır). Bunun nedeni olarak"raf hizmetlerinde görevli iyi yetiştirilmiş ve güdülenmiş personelin görev almaması" durumunun söz konusu olabileceği düşünülebilir.

$\diamond 44$ öğrencinin; ödünç verme, materyal ayırtma, bilgi kaynaklarına erişim ve yönlendirme, kablosuz internet ağı, kampüs dışından elektronik kaynaklara erişim, otomatik ödünç alma/verme ve fotokopi gibi kütüphane hizmetlerinden memnuniyet durumu oldukça yüksektir. 30 öğrenci ise, bu konuda fikir beyan etmemiştir.

$\diamond$ Ankete katılan öğrencilerin büyük bir çoğunluğu, kütüphane otomasyon programının; kullanılabilirlik, çalışma hızı ve (arayüzünün) kullanışııı̆ı açılarından olumlu değerlendirmektedir. 30 öğrenci bu konuda fikir belirtmemiştir.

Araştırmanın ikinci boyutunda ise, ankete katılan 74 öğrenciden 44'ünün Anadolu Üniversitesi ve geldikleri üniversitelerdeki kütüphane ortam ve hizmetlerine ilişkin genel görüşleri karşılaştırmalı olarak şu şekilde sıralanabilir:

$\checkmark$ Katılımcıların Anadolu Üniversitesi Merkez Kütüphanesi'nin iklimlendirme, aydınlatma, kullanım alanı genişliği, mobilya, bireysel çalışma odaları, oturma 
kapasitesi, kullanıc bilgisayarlarının yeterliliği, genel temizlik sessizlik vb. fiziksel özelliklerinden memnun olma düzeyleri $(\% 70,5)$ geldikleri üniversitenin kütüphanesine oranla $(\% 61,4)$ daha yüksektir.

$\checkmark$ Katılımcıların her iki kütüphanede verilen hizmetlerin nicelik/nitelik olarak kalitesine ilişkin görüşlerine bağlı olarak, kendi kütüphanelerinde hizmet kalitesinin $(\% 79,5)$ Anadolu Üniversitesi Merkez Kütüphanesi'ne $(\% 77,2)$ oranla daha yüksek olduğu ortaya konulmaktadır.

$\checkmark$ Katılımcıların kütüphanelerde çalışan personelin nicelik ve niteliğine ilişkin görüşlerine bağlı olarak, Anadolu Üniversitesi Kütüphanesi personelinin yeterliliği (\%75), geldikleri üniversite kütüphanesine $(\% 79,5)$ oranla daha düşük olduğu ortaya konulmaktadır

$\diamond$ Kütüphaneler, kullanıcılarının bilgi ve belge gereksinimlerini verimli bir biçimde karşılayabilmek için, ellerindeki kaynakları üretmek istedikleri hizmetlere göre planlamak durumundadır. Kütüphaneler bu planlama sürecinde, akademik birimlerin gereksinimleri doğrultusunda, derme geliştirme politikalarını oluşturmak durumundadır. Anadolu Üniversitesi Merkez Kütüphanesi, bu bilinçle yapılan bir araştırma (Yılmaz ve Kurulgan, 2007) neticesinde elde edilen bilgiler doğrultusunda stratejik derme geliştirme politikasını oluşturmuş durumdadır. Bu araştırmada, katılımcıların, dermenin nicelik ve niteliği açısından kütüphaneyi başarılı bulmaları, kütüphanenin derme geliştirme politikasının etkinliğinin bir göstergesidir.

$\diamond$ Çalışmada ayrıca "cinsiyet", "öğrencilerin geldiği ülke", "kütüphanede bulunulan süre", "kütüphane kullanım biçimi” ile "memnuniyet düzeyi" ögeleri arasında anlamlı bir ilişkinin varlığı incelendiğinde; bu değişkenler arasında anlamlı bir ilişkinin olmadığı saptanmıştır.

\section{Öneriler}

Araştırmanın sonuçları doğrultusunda, genel olarak, bu tür çalışmaların Türkiye'deki yükseköğretim kurumları arasında "Yerli Erasmus" olarak adlandıılan öğrenci değişim programlarına da yansıtılması önerilebilir.

Katılımcıların önemli bir bölümü $(\% 35,1)$ Anadolu Üniversitesi Kütüphanesi'ni hiç kullanmadığını, \%43,3'lük bir kısmı da düzensiz olarak kullandığını belirtmiştir. Bu bilgi, kütüphane yönetimini uyarması açısından önemlidir. Yılmaz'ın (2010, s. 47-48) Pinder'den (1996, s. 12-13) aktardığı ürün, tutundurma, bina, işgören, fiziksel durum ve işlemlerden oluşan kullanıcı memnuniyetini etkileyen ögelerin, kütüphane yönetimi tarafından, titizlikle gözden geçirilmesi ve kütüphanenin olumsuz yönlerini düzeltici önlemlerin alınması gerekmektedir.

Kütüphaneler -şu an için- her ne kadar kâr amacı gütmeyen örgütler olsa da ticari işletmecilik anlayışıla yönetilmeli ve bu sürecin tüm kütüphane personeli tarafından benimsenmesi sağlanmalıdır. 
Kütüphane personeli, kullanıcı gereksinimlerine yanıt verebilecek bilgi ve deneyime sahip olmalı, güven verebilmeli ve kullanıcı ile -belirli bir saygı çerçevesinde- bireysel olarak ilgilenebilmelidir.

Kullanıcılara daha etkin bir biçimde yardımcı olunması açısından raf hizmetlerinde iyi yetiştirilmiş ve güdülenmiş kişiler (paraprofesyonel) çalıştırılabilir.

Kütüphanelerin internet sayfalarında öneri/şikâyet olanaklarının bulunması kısa dönemde çözülmesi gereken sorunları anlamada kütüphane yönetimi ve kullanıcılar açısından yararlı olacaktır.

Yılmaz'ın da (2004b, s. 217) çalışmasında vurguladığı gibi; kütüphane personeli konusundaki memnuniyetsizlik düzeyleri, diğer ölçütlere göre daha düşük düzeyde olmakla birlikte, bu durum geliştirilmeli ve tam memnuniyet düzeyi hedeflenmelidir.

Katılımcılar Anadolu Üniversitesi Merkez Kütüphanesi'nde verilen hizmetlerin ve personelin nicelik/nitelik olarak kalitesini geldikleri üniversite kütüphanesine oranla daha düşük bulmaktadır. Sayısal olarak her iki kütüphane arasında, hizmet kalitesi bakımından, çok önemli bir fark görülmüyorsa da, öğrenci odaklı hizmet planlaması açısından önemli bir fark olarak değerlendirilmelidir. Çünkü müşteri odaklı yaklaşımda müşteri, organizasyonun varlık nedenidir. Bu bağlamda, tek bir müşterinin dahi memnuniyetsizliği, yönetimi rahatsız etmeli ve sorunu gidermek için gerekli önlemleri almaya zorlamalıdır. Kaliteli hizmet vermek ancak etkili bir iletişim ile mümkündür. Boyacı'nın (2011, s. 280) Anadolu Üniversitesi'ne gelen Erasmus öğrencileri üzerine yaptığı bir çalışmada, öğrencilerin Anadolu Üniversitesi’nde öğrenim gördükleri sınıflarda, geldikleri üniversiteye göre, daha resmi ancak daha etkili bir iletişimin olduğu yönünde görüş bildirdikleri vurgulanmaktadır. İletişim kültürü, bulunduğu kurumun bütün birimlerini de içine alan uygulama ve süreçler bütünüdür. Buradan hareketle Anadolu Üniversitesi'nin diğer birimlerinde olduğu gibi, kütüphanesinde de etkili bir iletişim ağı bulunmalıdır. Kullanıcı ile kurulan etkin bir iletişim, dış müşteriyi olduğu kadar iç müşteriyi de güdüleyip, onlarda tatmin duygusunu oluşturan bir ögedir. İşinden duyduğu memnuniyet derecesi yüksek bir işgören, kullanıcıya bunu doğrudan yansıtacak, böylece verdiği hizmetlerin de kalitesini artıracaktır. Bu doğrultuda Anadolu Üniversitesi yönetimine, personel özelliklerini tekrar gözden geçirmesi önerilebilir.

\section{Kaynakça}

AÜ Değişim Programları İstatistiği. (2012). 9 Kasım 2012 tarihinde http://www.uib.anadolu.edu.tr/ index.php?lang=tr\&mid=f718499c1c8cef6730f9fd03c8125cab\&mn=c4ca4238a0b923820dc c509a6f75849b adresinden erişildi.

Adomi, E. E. ve Iwhiwhu, B.E. (2004). User's levels of satisfaction with reserve collection services in a state university library in Nigeria. Collection Building, 23(1), 39-44.

Akbayrak, E. H. (2005). Orta Doğu Teknik Üniversitesi Kütüphanesi'nde hizmet kalitesi ölçümü. Yayımlanmamış yüksek lisans tezi, Hacettepe Üniversitesi, Ankara. 
Alkan, N. (1992). Üniversite kütüphanesi sisteminde kütüphaneci-kullanıcı etkileşimi. Türk Kütüphaneciliği, 6(3), 133-141.

Anlaşmalı Üniversiteler. (2012). 23 Aralık 2012 tarihinde http://www.uib.anadolu.edu.tr/index.ph p?lang=tr\&mid=7f39f8317fbdb1988ef4c628eba 02591\&mn=eccbc87e4b5ce2fe28308fd9f2a 7 baf3 adresinden erişildi.

Aslan, (Alpay) S. (1999). Kütüphane ve bilgi hizmetlerinde kalite yönetimi uygulamaları. Ö. Bayram ve diğerleri (Yay. Haz.). Bilginin Serüveni: Dünü, Bugünü ve Yarını... Türk Kütüphaneciler Derneği'nin Kuruluşunun 50. Yılı Uluslararası Sempozyum Bildirileri 17-21 Kasım 1999, Ankara içinde (s. 126-135). Ankara: Türk Kütüphaneciler Derneği.

Bir bakışta AB. (2011). 8 Kasım 2012 tarihinde http://www.abgs.gov.tr/index.php?p=3 adresinden erişildi.

Bologna Projesi. (2012) tarihinde http://www.ua.gov.tr/programlar/hayatboyu$\% \mathrm{C} 3 \% \mathrm{~B} 6 \% \mathrm{C} 4 \% 9$ Frenme-program\%C4\%B1/erasmus-program\%C4\%B1/alt-faaliyetler/ulusalajans-merkezli-faaliyetler/ bologna-projesi adresinden erişildi.

Boyacı, A. (2011). Erasmus değişim programı öğrencilerinin geldikleri ve Türkiye'de öğrenim gördükleri üniversitedeki sınıf yönetimine ilişkin karşılaştırmalı görüşleri: Anadolu Üniversitesi örneği. Eğitim ve Bilim, 36(159), 270-282.

Bozkurt, B. (2008). Hizmet pazarlamasında müşteri memnuniyeti ve kütüphane hizmetlerinde bir uygulama. Yayımlanmamış yüksek lisans tezi, Marmara Üniversitesi, İstanbul.

Bulgan, U. (2002). Kütüphanecilik sektöründe hizmet kalitesinin ölçümü ve bir üniversite kütüphanesi uygulaması. Yayımlanmamış yüksek lisans tezi, Beykent Üniversitesi, İstanbul.

Bural, İ. N. (2007). Avrupa Birliği yükseköğretim politikaları ve Türkiye: Avrupa yükseköğretim alanı, Erasmus ve Türkiye ilişkileri. Yayımlanmamış yüksek lisans tezi, Atılım Üniversitesi, Ankara.

Certel, S. S. (2010). Erasmus öğrenci değişim programına katılan Türk öğrencilerin akademik yaşantılarının nitel olarak incelenmesi. Yayımlanmamış yüksek lisans tezi, Yeditepe Üniversitesi, İstanbul.

Citti, A., Politi, A., Sabattini, F. ve Semenzato, C. (2012). User satisfaction surveys as decision making resources at the University of Bologna. Library Management, 33(3), 142-150.

Çağlayan, P. (2011). Halk kütüphanesi hizmetlerine ilişkin kullanıcı memnuniyeti. Bilgi Dünyası, 12(2), 379-398.

Çanak Akbaytürk, T. (2006). Kütüphanelerde kullanıcı memnuniyeti anketleri: Koç Üniversitesi Suna Kıraç Kütüphanesi deneyimi. A. Yıldızeli ve H. K. Bahşişoğlu (Yay. Haz.), ÜNAK '05 Bildiriler: Bilgi Hizmetlerinin Organizasyonu ve Pazarlaması: 22-24 Eylül 2005 İstanbul içinde (s. 181-191). İstanbul: Kadir Has Üniversitesi.

Çapar, B. (1990). Kullanıcı incelemeleri. Türk Kütüphaneciler Derneği 40. Yıl Kütüphanecilik Kurultayı (30 Kasım-1 Aralık 1989, Ankara: Bildiriler içinde (s. 171-177). Ankara: Türk Kütüphaneciler Derneği.

Çukadar, S. (1999). Toplam Kalite Yönetimi'nin kütüphanelerde uygulanması: İstanbul Bilgi Üniversitesi Kütüphanesi için Toplam Kalite Yönetimi sisteminin geliştirilmesi. Yayımlanmamış yüksek lisans tezi, İstanbul Üniversitesi, İstanbul. 
Danuta, A. N. (1996). Changing the concept and measure of service quality in academic libraries. Journal of Academic Librarianship, 22, 181-190.

Erasmus: Genel bilgi. (2012). 24 Aralık 2012 tarihinde http://www.ua.gov.tr/programlar/hayatboyu\%C3\%B6\%C4\%9Frenme-program\%C4\%B1/erasmus-program\%C4\%B1 adresinden erişildi.

Erasmus: Yayınlar ve istatistikler. (2010). 23 Aralık 2012 tarihinde http://www.ua.gov.tr/docs/ erasmus-/2008-hareketlilik-sayilari.pdf?sfvrsn=0 adresinden erişildi.

Erasmus hakkında genel bilgiler. 06 Kasım 2012 tarihinde http://ziraat.uludag.edu.tr/erasmus/ genel_bilgiler.pdf adresinden erişildi.

Erdem, S. (1995). Hacettepe Üniversitesi Kütüphanelerinde kullanıcı tatmini. Yayımlanmamış yüksek lisans tezi, Hacettepe Üniversitesi, Ankara.

Göksan, T.S., Uzundurukan, S. ve Keskin, S.N. (2011). Değişim programlarının genel yapısı, işleyişi ve kazandırdıkları. S. Altın (Yay. Haz.), Inşaat Mühendisliği Eğitimi 2. Sempozyumu: Bildiriler kitabı 23-24 Eylül 2011 Muğla içinde (s. 191-200). Muğla: TMMOB İnşaat Mühendisleri Odası.

Hakkımızda. (2012). 23 Aralık 2012 tarihinde http://www.uib.anadolu.edu.tr/index.php? lang $=\mathrm{tr} \& \mathrm{mn}=\mathrm{f} 7177163 \mathrm{c} 833 \mathrm{dff} 4 \mathrm{~b} 38 \mathrm{fc} 8 \mathrm{~d} 2872 \mathrm{f} 1 \mathrm{ec} 6$ adresinden erişildi.

Hiller, S. (2001). Assessing user needs, satisfaction, and library performance at the University of Washington libraries. Library Trends, 49(4), 605-625.

Hitchingham, E.E. ve Kenney, D. (2002). Extracting meaningful measures of user satisfaction from LibQUAL+TM for the university libraries at Virginia Tech. Performance Measurement and Metrics, 3(2), 48-58.

Hossain, M.J. ve Islam, Md. A. (2012). Understanding perceived service quality and satisfaction. Performance Measurement and Metrics, 13(3), 169-182.

İşeri, A. (2005). Avrupa Birliğ giriş sürecinde Erasmus Programı uygulamasına ilişkin uzman görüşleri. Yayımlanmamış yüksek lisans tezi, Abant İzzet Baysal Üniversitesi, Bolu.

Kapucu, H. H. (2007). Kütüphane hizmetlerinde müşteri tatmini ve bir uygulama. Yayımlanmamış yüksek lisans tezi, Marmara Üniversitesi, İstanbul.

Karahan, Ş. (2012). Kütüphanelerde hizmet kalitesinin LibQUAL $+^{T M}$ hizmet kalitesi ölçüm anketiyle ölçülmesi: Dumlupınar Üniversitesi Merkez Kütüphanesi üzerine araştırma. Yayımlanmamış yüksek lisans tezi, Dumlupınar Üniversitesi, Kütahya.

Karakaş, S. (1999a). Üniversite kütüphanesi kullanıcılarının beklentileri ve kullanıcı tatmini. Ankara Üniversitesi Dil ve Tarih-Coğrafya Fakültesi Dergisi, 39(1-2), 57-66.

Karakaş, S. (1999b). Üniversite kütüphanesinde bir pazarlama aracı olarak hizmet kalitesinin araştırılması. Türk Kütüphaneciliği, 13(3), 207-222.

Karakaş, S. (1999c).Üniversite kütüphaneleri hizmetlerinde kullanıcıya dönük yaklaşım. E. Bilar (Yay. Haz.). 21. Yüzyılda Üniversite Kütüphanelerimiz Sempozyumu Bildirileri (22-24 Ekim 1998) içinde (s. 6-15), Edirne: Trakya Üniversitesi.

Kehm, B. M. (2005). The contribution of international student mobility to human development and global understanding. Online Submission, US-China Education Review, 2(1), 18-24. 
Keser, E. (2007). Üniversite kütüphanelerinde kullanıı memnuniyeti ölçümü. Yayımlanmamış yüksek lisans tezi, İstanbul Üniversitesi, İstanbul.

Kılıç, N. (2007). An instrument for measuring the critical factors of service quality in university libraries: An application of Fatih University. Yayımlanmamış yüksek lisans tezi, Fatih Üniversitesi, İstanbul.

Kurulgan, M. (2004). Bilgi teknolojisinin üniversite kütüphanelerinde yönetim işlevleri üzerine etkileri ve Türkiye'deki uygulamaya ilişkin bir araştırma. Yayımlanmamış doktora tezi, Anadolu Üniversitesi, Eskişehir.

Kurulgan, M. (2007). Bilgi ve belge hizmetlerinde mükemmeli yakalamak: Örnekedinme. Bilgi Dünyası, 8(1), 30-48.

Kurulgan, M. (2009). Bilgi-belge merkezlerinin yönetimi: Türkiye'deki literatüre yönelik içerik analizi. Bilgi Dünyası, 10(2), 205-230.

Kurulgan, M. ve Temizel, F. (2007). Üniversite kütüphanelerinde bütçe dışı finans kaynaklarının kullanımı ve Türkiye'deki üniversite kütüphaneleri için alternatif finansman modeli önerisi. Türk Kütüphaneciliği, 21(4), 459-475.

Milli Kütüphane Başkanlığı (2011). Milli Kütüphane kullanıcı memnuniyet analizi: Haziran-Aralık 2011). 21 Aralık 2012 tarihinde http://www.mkutup.gov.tr/menu/216 adresinden erişildi.

Mirici, H. İ. ve Saka, Ö. (2009). Eğitim amaçlı değişim programları ve Erasmus yoğun dil kursları: Türkçe kursları için bir örnek olay. Eğitim ve Bilim, 34(152), 148-159.

Nitecki, D. A. ve Hernon, P. (2000). Measuring service quality at Yale University's Libraries. Journal of Academic Librarianship, 26, 258-273.

Öndoğan Gedikçi, A. (2010). Üniversite kütüphaneleri tarafından yürütülen halkla ilişkiler faaliyetlerinin müşteri memnuniyeti üzerine etkisi: Selçuk Üniversitesi Merkez Kütüphane örneği. Yayımlanmamış yüksek lisans tezi, Selçuk Üniversitesi, Konya.

Özler, Z. (2012). IKV değerlendirme notu: Erasmus öğrencilerinin vize bağlantılı sorunları. İstanbul: IKV. 18 Aralık 2012 tarihinde http://www.ikv.org.tr/images/upload/data/files/degerlendirme_ notu_-_erasmus_tr.pdf adresinden erişildi.

Pinder, C. (1996). Customers and academic library services : An overwiev. C. Pinder ve M. Melling (Yay. Haz.). Providing customer-oriented services in academic libraries içinde (s. 1-24). London: Library Association and SCONUL.

Powelson, S.E. ve Reaumet, R.D. (2012). Using the results of a satisfaction survey to demonstrate the impact of a new library service model. Health Information and Libraries Journal, 29, 223232.

Shafique, F., Rehman, S.U. ve Mahmood, K. (2012). A macro sketch of users' needs, satisfaction, and library performance: A survey of university libraries in Pakistan. Library Philosophy and Practice (e-journal). Paper 815. 16 Şubat 2013 tarinde http://digitalcommons.unl.edu/libphilprac/815 adresinden erişildi.

Sarıtaş, E. (2011). Avrupa Birliği Erasmus programına katılan Türk ve yabancı öğrencilerin programla ilgili görüşlerinin karşılaştırılması. Yayımlanmamış yüksek lisans tezi, Uludağ Üniversitesi, Bursa.

Stephens, D. (1997). Managing the web-enhanced geographic information services. Journal of Academic Librarianship, 23(6), 498-504. 
Tabak, Y. (2009). Bilgi ve belge merkezlerinde hizmet kalitesinin artırılmasına yönelik bir uygulama: Marmara Üniversitesi Merkez Kütüphane'si örneği. Yayımlanmamış yüksek lisans tezi, Marmara Üniversitesi, İstanbul.

Tarihçe ve genel bilgiler. (2012). 21 Şubat 2012 tarihinde http://www.kdm.anadolu.edu.tr/ hakkimizda.html adresinden erişildi.

Uçak (Özenç), N. (1997). Bilgi merkezi için mi kullanıcı, kullanıcı için mi bilgi merkezi?. B. Yılmaz (Yay. Haz.), Kütüphanecilik Bölümü 25. Yıla Armağan içinde (s. 242-248). Ankara: Hacettepe Üniversitesi Kütüphanecilik Bölümü.

Üstün, A. (2001). Bilgi hizmetleri ve hizmetin kalitesi. Türk Kütüphaneciliği, 15(2), 205-213.

Visakorpi, J., Lewis, R., Ufert, K. ve Smith, J. (Haz.). (2010). Anadolu Üniversitesi EUA kurumsal değerlendirme raporu. Eskişehir: Anadolu Üniversitesi.

Whitehall, T. (1994). Quality in library and information service: A review. M. O'Neil (Yay. Haz.). Total quality management in libraries: A sourcebook içinde (s.100-121). Eglewood, Colorado: Libraries Unlimited.

Yılmaz, A. ve Kurulgan, M. (2007). Çevrim-Içi (On-Line) veri tabanlarının kullanım analizi: Anadolu Üniversitesi Kütüphane ve Dokümantasyon Merkezi örneği, A. Üstün ve Ü.Konya (Yay. Haz.). I. Uluslararası Bilgi Hizmetleri Sempozyumu: Illetişim 25-26 Mayıs 2006, İstanbul (Bildiriler) içinde (s. 35-63) İstanbul: Türk Kütüphaneciler Derneği İstanbul Şubesi.

Yılmaz, E. (2001). Kütüphanelerde değişim ve Toplam Kalite Yönetimi. MPM Anahtar Dergisi. Aralık, 18-19.

Yılmaz, E. (2003). Üniversite kütüphanelerinde kullanıcı merkezli yapılanma: Hacettepe Üniversitesi örneği. Yayımlanmamış doktora tezi, Hacettepe Üniversitesi, Ankara.

Yılmaz, E. (2004a). Üniversite kütüphanelerinde müşteri merkezli yapılanma. Türk Kütüphaneciliği, 18(3), 261-292.

Yılmaz, E. (2004b). Üniversite kütüphanelerinde Toplam Kalite Yönetimi ve kullanıc memnuniyeti. Hacettepe Üniversitesi Edebiyat Fakültesi Dergisi, 21(1), 203-218.

Yılmaz, E. (2005). Bilgi merkezlerinde Toplam Kalite Yönetimi. Ankara: Alp.

Yılmaz, E. (2010). Kütüphanelerde toplam kalite yönetimi: Kısa bir gözden geçirme. Türk Kütüphaneciliği, 24(1), 33-62. 